\title{
THE ATTITUDES OF THE CONTEMPORARY POLES TOWARDS THE ARCHAEOLOGICAL PAST
}

\author{
POSTAWY WSPÓŁCZESNYCH POLAKÓW \\ WOBEC ARCHEOLOGICZNEJ PRZESZŁOŚCI
}

\author{
Michat Pawleta \\ https://orcid.org/0000-0002-0466-1901 \\ Wydział Archeologii Uniwersytetu im. Adama Mickiewicza \\ ul. Uniwersytetu Poznańskiego 7, 61-614 Poznań \\ mpawleta@amu.edu.pl
}

\begin{abstract}
This paper aims to present how the past is viewed in contemporary cultural and social narratives, and defines contemporary attitude to the past among Poles. My deliberations are placed in the context of the present-day society / culture and their constituting processes, namely the phenomenon of forgetting the past, democratization of the past, its privatization / individualization, commodification of the past and new ways of experiencing it. The paper will specifically concentrate on the archaeological past - that is the past created by archaeologists, and on archaeological heritage. It address three crucial issues, namely: (1) how changes in the historical context of post-1989 Poland influenced the emergence the renaissance of the past and different narratives about it; (2) what are the most important and widespread forms of presenting and/or experiencing the archaeological past in the present?, and (3) what are the main motivations that lie behind contemporary Poles interest in the past, archaeological heritage and activities undertaken around it? Finally, it is argued that the changes in the people's attitudes towards the past have led also to a transformation in the hierarchy of aims and methods in education and dissemination of the knowledge about the past within institutions concerned with the past on a professional level.
\end{abstract}

KEYWORDS: historical culture, archaeological heritage, commercialisation, democratisation of the past, archaeological reconstructions, archaeological festivals, historical re-enactment

In the following paper I present how the archaeological past is viewed in contemporary cultural narratives. Its main objective is to define a specific, present-day attitude to the past. I assume that the understanding and significance of the past and images of it, remain closely connected to the culture which shapes and creates them and which also influences people's attitudes to the past. The significance of the past 
throughout history has undergone transformations along with the changes in the historical context in which it was created. Likewise, changes in culture and how reality is perceived in the present era have led to a re-evaluation of people's attitudes towards the past.

I propose that contemporaneity is marked by fundamental re-evaluation of the forms in which the past is perceived / made present / experienced. The nature of the dynamic cultural, social, political, economic and civilizational changes that shape it formulates quite new context for the presence and functioning of the past. These changes condition contemporary attitudes towards the past, visions of the past, opinions on its function and meaning in today's world, as well as how we relate to the past, discover or experience it and the way it is presented to the public.

The selected formula for the argument in the following paper is not a complete register of all the phenomena. Quite the opposite, it is rather problematic and relies on a complex analysis, based on selected examples of archaeological projects, certain wider issues, phenomena and trends, characteristic of the post-1989 period. The selection of subjects was purely arbitrary, resulting from the hierarchisation and interconnection of certain facts, followed by the analysis of issues identified as necessary if the aims of the article were to be fulfilled. It is not concerned with unification in so much as indicating variety, the many aspects of the past and the interdependent forms in which it is present, the strategies involved in its construction and presentation or in how it is experienced ${ }^{1}$.

\section{CONTEMPORARY CHANGES IN ATTITUDES TOWARDS THE PAST AND HERITAGE}

Generally speaking, the beginning of changes in attitudes to the past can be observed through phenomena that appeared in Great Britain, the United States and many West European countries much earlier than in Poland, as already in the early 1980s. They have been analyzed thoroughly (Lowenthal, 1985, 1996; Hewison, 1987; Fowler, 1992; Walsh, 1992; De Grott, 2008; Macdonald, 2013), and constitute a valuable inspiration for deliberations presented here. In the case of Poland, the intensification of certain processes led to the formation of a specific approach to the past and cultural heritage, the features of which have been observed since the mid-1990s, with the intensity in the first decades of a present century. The limiting moment can be conventionally assumed to be 1989 and the changes initiated with the political transformation, the shaping of the democratic system and the transformations of contemporary culture, including historical culture in Poland.

\footnotetext{
${ }^{1}$ Some of the observations and ideas presented here have been already the subject of my previous publications and have appeared elsewhere (see Pawleta, 2011, 2012, 2016, 2017, 2018a, 2018b, 2019). This saves me from having to tackle these aspects again. Here my aim is to summarize them and conceptualize some of these ideas anew.
} 
Since 1989, essential changes in Polish society's memory and attitude towards the past have taken place. They have been caused by two complex factors: firstly, by a general switch in Western culture that has taken place during that period and secondly, by the new, radically different political situation of Polish society. As Andrzej Szpociński (2010, p. 45) has pointed out, hybridization and a new sense of time have been the most important tendencies from the Western culture, and as for the political dimension democratization and the opening of society to the world after the fall of the Iron Curtain. The abovementioned changes have stimulated substantial reappraisal in the historical culture of Polish society and gave rise to the development of a historical sensitivity, which ought to be understood as

a collection of ideas, norms, behavioural models, socially respected values, which regulate the way we relate to everything, what is recognised as the past (passed, historical) in any given culture, independent of the current state of affairs. (Szpociński, 2010, p. 9)

Numerous research carried out by sociologists and cultural studies academics (e.g. Szpociński, 2004a, 2004b, 2005a, 2005b, 2005c, 2007, 2009, 2010a, 2010b, 2012; Kwiatkowski, 2008, 2009, 2012, 2014; Szacka, 2009, 2014; Tarkowska, 2012; Kukołowicz, Maciejczak, Wiśniewski, 2018) clearly reveal that the present days have instigated a totally new quality in the ways history and the past are perceived, which elsewhere I suggested be termed 'the postmodern attitude to the past' (Pawleta, 2016, p. 39-75). For example, the results of the extensive surveys on the collective memory of the Polish society during the period of transformation was presented by Piotr T. Kwiatkowski (2014). They were based on empirical sociological research and public opinion pools and addressed many issues, as commercialisation of the past, development of historical re-enactment in Poland, functioning of memory regarding family history, the transformations in the canon of vernacular national memory, and the memory of communism. They proved that in contemporary culture we have been dealing with commemorations typical of past epochs, which is reflected in the constant use of religious symbolism as a carrier of memory, erecting monuments, or recreating the rituals of anniversary celebrations. On the other hand, more and more often social memory is expressed in a number of new forms, stimulated by new communication technologies, archiving, etc., but also in activities indicating new ways of experiencing the past, based on sensual (aesthetic) and emotional involvement in performances recreating past events.

The undertaken surveys and studies on participation of Poles in contemporary historical culture confirm the view shared by the majority of Poles that heritage of the past is important to the present - almost three-quarters of respondents in 2003 and in 2016 believed that knowledge about the past is needed by modern people (Raport, 2016). The obtained data confirm that interest in history and emotional attitude to it occupy one of the central places of Polish national identity and everyday practice in which this identity is manifested. For example, Artur Wysocki (2018) analysed the problem of the significance of history and history attributed to contem- 
porary Polish society in the context of national identity, trying to answer, amongst other, to what extent Poles are interested in the history of their own country?; how much is the history of the national community the source of pride or shame?; and to what extent is knowledge of history in postulated patriotic attitudes and is at all an important criterion for recognizing someone as a Pole? The conducted analysis led him to the conclusion that the common past is one of the key elements of the contemporary national identity of Poles.

Also, Barbara Szacka $(2009,2014)$ indicates that changes of attitude to the past after the system transformation in 1989 refer to decline of interest in history, shortening the time horizon, interest in local history and in family history, individualism, corporeality, sensuality, and commercialisation. We shall also recall here numerous publications of Andrzej Szpociński who proposes to approach the past as an element of contemporary culture and to see it as a derivative of wider socio-cultural changes. Thus, as he argues, certain trends towards the past are parallel to general changes occurring in culture and social life. He has also pointed attention to the aspects of authenticity of the representations of past in the present (Szpociński, 2005a), sensitivity/visual aspects of present-day historical culture (Szpociński, 2008), and also elaborated on so called 'spectacles of the past' (Szpociński, 2012) - new forms of theatricalization, reconstruction and performances of the past - which constitute new and popular ways of experiencing the past in contemporary historical culture. Although abovementioned observations refer mostly to the recent history and events from $19^{\text {th }}$ and $20^{\text {th }}$ centuries, I argue that in many cases they can be extended also to the past that is the subject of reference of archaeology.

The political and economic turning-point in Poland in 1989, accompanied by concurrent processes and changes, have also altered approaches to cultural heritage along with accompanying changes in the monument preservation. The former includes changes in form of ownership, responsibility and financing for monuments, monument status and the position of the conservation office (Szmygin, 2007, p. 131). As far as monument status is being concerned, a change in its ontological status can be observed. While in a preceding epoch a monument had the status of an element of the past, now heritage has the status of the present and its main purposes are contemporary (Szmygin, 2007, p. 134). As a consequence, as Monika Murzyn (2007, p. 140) observes, "in the new reality heritage has ceased to be considered solely an element of a non-productive 'superstructure' and has largely become a market asset".

These profound changes to perception of heritage have also been reflected in undertaken surveys and opinion pools. For example, the social survey conducted in 2015 at the request of the National Heritage Board of Poland intended to determine the manner in which Poles perceive their own heritage (Chabiera, et al., 2017). It appeared that in general they consider heritage to be a matter of great importance. Poles perceive heritage as a source of their identity and consider it as having an impact on perception of the world around them, on their attitudes, en- 
trepreneurship or, in a more general sense, on the growth of social capital. Being an endogenic growth factor, heritage may also serve as a source of competitive advantage. Heritage comes into its own, becoming an important factor of existence of various groups within society rather than remaining some abstract, exalted value which one is simply bound to protect by its very nature. In another survey that was conducted in 2011 the question of the role of heritage in building social coherence and social capital was investigated (Kozioł, Florjanowicz, Trelka, 2013). It also addressed how heritage improves the quality of life and how it can be utilized in urban and sustainable countryside development. It proved that the majority of the respondents perceive national heritage as an ensemble of tangible and spiritual achievements of a nation: traditions, customs, and values. The majority of them agree that heritage plays an important social role. As far as what the most important value of a monument is considered, over half of those interviewed answered that it gives a testimony to our common history. The vast majority of Poles consider also heritage as something which holds an economic value and may therefore have an impact on economic growth. Around half of the participants of the survey answered that monuments play a role in tourism development, which is a source of income for the local community. The majority of respondents also said that it is worth investing public money in heritage.

An attempt to isolate and characterise contemporary attitude to the past among Poles seems to be a particularly difficult task since there is no single unified or universal formula. Still, it is possible to identify several elements involved. They shall be located in the context of two conflicting concepts - the phenomenon of forgetting the past, a consequence of the presentist option of referring to time that is currently dominant (Tarkowska, 2012, p. 25), and the renaissance of the past in the contemporary world - the so called 'explosion of memory' as an astounding, multidirectional and multifaceted rise in interest in the past (Tarkowska, 2012, p. 17). In the second instance we can refer to, for example, Hermann Lübbe's idea of musealisation (Lübbe, 1991) or Pierre Nora's coming of the time of memory (Nora, 2010).

A couple of interrelated aspects which constitute the change in today's attitudes towards the past can be listed, namely: (1) the increasing importance of memory in public life; (2) democratisation of the past; (3) the privatisation of the past, based on creating personalised visions of the past; (4) the conviction that direct contact with the past is possible through personal and sensuous experience; (5) the commercialisation of the past / cultural heritage, connected with the transformation of the essence of the past into a marketable product in the form of goods, services or experiences; (6) a search for identity and new forms of spirituality (Kwiatkowski, 2008, p. 39-40; 2009, p. 131-134).

In the following part of the article I discuss some of abovementioned tendencies in more details. I pay attention especially to characteristic elements defining the nature of the present-day attitude to the past as evidenced through archaeology and activities undertaken around archaeological heritage. 


\section{DEMOCRATISATION AND PRIVATISATION OF THE ARCHAEOLOGICAL PAST}

The democratisation of the past refers to the pluralisation of the past (and memory) and changes in how it is imagined. It is treated as a consequence of different independence movements, of groups or units, demanding justification and the reconstruction of identity, the need for self-definition, for writing personal histories or for the transformation of memory of what is past and for the reinterpretation of history (Krajewski, 2003, p. 208). Democratisation permits the existence of many possible and competing images of the past which brings it back into the present through all kinds of contemporary rituals and present-day narratives. In this way the existence of only one version of history as established by professional historians or archaeologists and 'intellectual introversion' (Jameson, 2008, p. 1530) is questioned. Democratisation also allows alternative visions of the past to exist and emerge, beyond the domain of academic professionals.

Observation of public discourse leads to the conclusion that interest in the past among Poles is high and has been systematically growing in recent years. This is particularly evident in the number of popular science publications, radio and TV programs, film and serial productions available, as well as content posted on the Internet. Most of them, however, create a phenomenon that can be described as 'pop-history', i.e., creativity directed at a wide audience, showing the past in a simplified, selective, and often sensational way. It is a direct reflection of a situation where history is democratized (Samuel, 1994; de Groot, 2008) and there is an increasing participation of non-academics or even non-professionals in creating visions and representations of the past in the contemporary social space (Baraniecka-Olszewska, 2019, p. 156).

One element that refers to increased participation of amateur in creating visions of the past is historical re-enactment movement. It can be defined as

activities based on the visual presentation of various areas of life in the past by people in costumes using objects relating to the past (replicas or occasionally reconstructions) for a given period, even relatively original artefacts. (Bogacki, 2008, p. 222)

It involves the staging of past events, the aim of which is to present the past based on historical or archaeological facts, it is not a truthful recreation of the past. We can distinguish two types of historical re-enactment, namely battle reenactment, which reconstructs battle scenes, and living history, recreating aspects of everyday life, presenting either a full picture or only part of it (Bogacki, 2008, p. 227-228). The character of the re-enactment movement is spontaneous, grassroots, created by groups and independent societies (often in cooperation with local cultural institutions), focusing on recreating a given period of the past. Historical reconstructions have become one of the most popular ways of delivering knowledge about the past to the public. The re-enactors' motivations are complex and multiple. They are not separate as it often happens that several motivations lie behind ones joining the group. They include: 
fascination with history and military, willingness to escape the routine and dullness of everyday life, respect for the spirit of patriotism and love for cultural heritage (sometimes a local one), building new relations and enriching the social capital, pursuit of extreme experiences, showing-off and 'promoting' oneself, and pursuing an economic motive (Szlendak, et al., 2012, p. 13-22; Olechnicki, Szlendak, 2020, p. 8).

The form of re-enactment events enables their witnesses to highlight the personal and human dimensions of the history evoked and experience the past in a personal human dimension. Moreover, the interest of ordinary 'non-heroic' families in their own past translates into interest in the local, regional pasts. Thus, in spite of the fact that re-enactment events are supposed to provide the spectators mainly with entertainment, this movement has considerable potential in influencing the Poles' knowledge of their own history and the microhistory of the place that they live in (Olechnicki, Szlendak, 2020, p. 5).

Another illustration of the democratisation of the past is a phenomenon popular in contemporary culture, especially in the Internet sphere, namely the Great Lechia or 'TurboSlavs' (Kośnik, 2019, p. 199-200). It is a spread-out of the academia historical narrative of an alleged ancient empire of Slavs that used to occupy the area of almost whole Europe. This democratic and highly developed state is thought to be the greatest political-military power in its region since about 1800 B.C.

Its greatness was supposed to manifest itself in the territorial conquests and successful wars against such dangerous enemies as the Roman Empire, as well as superior standard of living and level of cultural and social progress. Due to narratives, modern Poland is a successor of the Great Lechia empire so Poles are believed to be 'the most Slavic' amongst all of Slavic peoples. According to followers of these narratives the Empire collapsed as a result of a Jewish-Christian-German conspiracy that aimed to destroy the most magnificent and powerful political-cultural structure ever existing. (Kośnik, 2019, p. 200)

The Great Lechia narratives are widespread not only in the Internet, but also in books than can be found in the leading bookstores in Poland. The most influential author is Janusz Bieszk (2015, 2017a, 2017b, 2019), who wrote four extensive monographs in order to prove the Lechites empire existence. What is characteristic of Bieszk's and his followers' narratives is that they stand against findings of academic research. A methodology applied by most of the authors is similar to the methodology of the pseudoscience publications. It is characterized by the distrust to the scientific historic and archaeological data and they promise to obtain the 'true' knowledge contrary to conclusions of academic historians. Further, they treat amateur linguistic and source analyses as proof of the ancient imperial might of the Slavs, or selectively use scientific knowledge for the purpose of validating their own claims. The last element can be observed in the references to the latest findings on population genetics (haplogroup R1a Y-DNA) (Kośnik, Filipiuk, 2016, p. 85). However, Bieszk and other 'Turboslavs' maintain that their arguments are grounded in the historical sources. For example, they derive their theories from the so-called "Chronicle of Prokosz" "discov- 
ered' in the early 19 th century that was proved to be a 18th century forgery debunked as such a year after it was published.

A phenomenon of the Great Lechia refers to a wider issue of growing distrust to science and academic research conclusions and

gaps in historical sources and a lack of familiarity within the greater society with the current consensus among academic scholars result in amateur efforts to replace the lacunae in our historical knowledge with the creation of stories about the nation's or our ethnic group's history that depart from the official' scholarly record. (Kośnik, Filipiuk, 2016, p. 82)

Moreover, it also relates to the problem of identity shaping and construction of group identity of contemporary Poles and reflects the process of researching the historical identity sources in comparison with the modern phenomenon of the deconstruction of identity as characteristic for the Western, individualistic societies (Kośnik, 2018 , p. 61). It results in the formation of an image of history that, while clashing with the actual findings of scholars, testifies to the needs, desires or fears of its creator (Kośnik, Filipiuk, 2016, p. 84). Slavic topics and the Slavic kings of Lechia are an element in this phenomenon extremely important because they respond to the need for phantasmatic creation the image of the Slavs and Poland as an eternal power. Yet, the very mechanisms for constructing Great Lechia narratives reflect the ethno-national identity of their creators (Kośnik, Filipiuk, 2016, p. 85) - the Slavs' antiquity and their exceptionality are thought to be demonstrated by their descent from the Aryan race (Kośnik, Filipiuk, 2016, p. 85-86). Although these narratives have been heavily criticised by scholars (Żuchowicz, 2018; Wójcik, 2019), nowadays a certain group of young Poles try to answer the question of their identities using the Slavic, pre-Christian culture's content which frequently leads them not to the academic knowledge but to non-academic historical narrations (Kośnik, 2018, p. 57).

\section{NEW FORMS OF SENSITIVITY TO THE PAST}

The historical culture of almost the entire 20th century was an intellectual one, and the past was distinguishable by signs and symbols that needed to be intellectually decoded (Szpociński, 2010a, p. 16). However, it is gone and now and it can be said that a new form of historical sensitivity is constituted by the approach to the past where sensualism dominates over intellectualised forms of contact with the past (Szpociński, 2005c, p. 298). It is characterised by the emphasis on a sensuous, not necessarily intellectual, experience of the past (Szpociński, 2007, p. 42). According to Andrzej Szpociński (2010a, p. 16), the current, visual era of human historical culture, is dominated by non-verbal communication, images, happenings, performance: it is not intellect, but rather the senses which play the key role in the experience of the past, delivering specific aesthetic experiences to the audience. 
One can distinguish between two basic functions of the past as perceived through senses: firstly, as a source of aesthetic experience, and secondly, as enabling participation in the community made of participants in the performance. I will focus on the first element.

Aesthetisation of the past can be seen in many forms, such as the blurring of the boundaries between fiction and reality and mixing facts with conjectures. Also, it can be seen in bringing the past 'to life', in reshaping fragmentary knowledge about the past into the form of complete, in theatrical presentations of life in olden days, in creating certain sterilised, idyllic images of the past, devoid of aspects of cruelty or human misery, etc. An excellent example of such an approach are archaeological fêtes and historical re-enactment spectacles. One aspect of the rationale behind them is inseparably connected to the simulation of aesthetisation of the past and the sensory experience of the past. Elements of the aesthetisation of the past, as a result of which the image of the past becomes more aesthetically pleasing can be found in processes 'reanimating', recreating or staging the past, and in the different ways the past can be experienced. Such a mode of aesthetisation depends above all on creating a whole, giving an impression of being complete, coherent. Furthermore, the aesthetisation process can also be related to the beautification of the past and images of it in a certain way.

In this context an important constituent element of archaeological fêtes and historical re-enactment spectacles is that they also offer a sensory and personal contact with the past - aesthetisation can therefore also be seen in the move towards the direct, sensory experience of the past and reconstructions of it, the emotional experience. These open air events with the past as a theme usually take place where some connection to the past already exists (e.g., in open-air museums) or nearby and a range of aspects from the material, social or spiritual world of the past are presented (Chowaniec 2017, p. 239). Contact with the past during fetes and other ways of staging the past is based on active participation, everything can be touched, visitors can have a go at making something themselves or discover how things actually work. What attracts the audience is the possibility of experiencing the past personally by, e.g., hand-forging an ornament or a fragment of a weapon, striking a coin, shooting a bow or tasting a flatbread. They also include demonstrations of different crafts such as pottery and flint tool making or weaving, it is possible to see a blacksmith at work, a carpenter, a bone and horn craftsman, old recipes are used to cook traditional dishes, there are scenes from everyday life, warriors in battle, traditional folk music concerts, etc. 'The Slavs and Vikings Festival' in Wolin is an excellent example here, where

visitors can wander through a warriors' encampment, see reconstructed armour and weapons, and listen to the reenactors' stories about the past they have recreated. They can also buy craft items such as pottery, jewellery, or textiles made according to early medieval methods. However, the most popular event is a staged battle between tribes which could have been fighting with each other, although there are no sources to confirm that they in fact did so. (Baraniecka-Olszewska, 2019, p. 163) 
Thus, emotions, feelings, the authenticity of experience, perceptual contact with the surrounding generated by all senses and based on closeness, participation and personal experience, constitute the essence of this approach (Tarkowska, 2012, p. 37). Consequently, during such events, a 'recalled past' oscillates between emotions and the visitor's interaction, the viewer is frequently asked to participate in the events, giving rise to emotions through 'sensuous intensification', providing an extraordinary experience. Moreover, the fact that it is possible to take a look 'behind the scenes' at such events is important minimises the distance between the player and the spectator, creating the illusion viewers have of being in direct contact with the past (Nieroba, Czerner, Szczepański, 2009, p. 31-33).

It is not only visitors, but also performers who playing the roles of their ancestors want to experience how life might have looked centuries ago for themselves. Such 'journeys into the past' are mainly based on personal, direct contact with the past: reenactors attempt to live as people actually did in the period that interests them (Bogacki, 2007, p. 204), making past reality tangible and accessible mainly through sensory elements, through physical experience, e.g., by wearing costumes from the past, incorporating replicas of historical weapons or living in historical camps in order to achieve the most faithful recreation of the atmosphere of a time passed. One of the aims of such initiatives is verifying adaptive abilities for being in conditions that people today find difficult for an extended length of time. They also enable more knowledge to be gained on the subject of the past in a direct way, based on a personal experience.

\section{COMMODIFICATION OF THE ARCHAEOLOGICAL PAST}

Another characteristic feature of the present-day attitude to the past is its commodification. It is dictated by, among others, the demands of a free market economy as well as wider socio-cultural changes. The result is the transformation of elements of the past, its heritage, and knowledge of the past into a commercial product for which a demand in society exists. This phenomenon depends on the display, sale and consumption of the past (history) as a product with a market value and the attempts to create recognisable marketing merchandise (Urry, 2007, p. 154-198). The subject of commercialisation can be the past, in the form of its material relics (monuments) or copies of them, as well as narratives about the past based on these relics (books, archaeological reconstructions, reenactments, fêtes, films, etc.). It can also be observed in heritage boom and development of cultural tourism industry. The consumption and commercialisation of the past from which it is inseparable cannot be narrowed down to only the sale and acquisition of certain products or goods, as leisure and entertainment, events and shows, narratives and stories, aspects of the sensory experience of the past - pleasant and special experiences - are also included. So it is with this in mind that one must now concur with Marek Krajewski's (2003, p. 210) observation: "the past is becoming ever more accessible, but rather as a consumer product for en- 
tertainment than as a basis for identity". As a result of commercialization, the past and its relics are more and more often treated as a 'resource' used for various purposes, and heritage as a deliberately created product, serving the satisfaction of human consumption needs, including the need for entertainment.

Commodification of the past is strictly connected with commercialisation of archaeology which is the result of archaeology functioning in an altered, market-oriented reality. It is to the way archaeology institutions are financed as well as the development of civilisation and social expectations. A number of examples provide evidence of the commercialisation of contemporary archaeology and the past, that includes, amongst other, the forms through which knowledge of the past is popularised and increasing competition in this field; the growth of archaeological tourism accompanied by the material exploitation of monuments; and/or the casual exploitation of history and its symbolism with purely commercial or marketing aims.

Symptoms of commodification of the archaeological past are especially evident in three tendencies, namely reconstructionism, festivalisation and theatralisation of the past. The first concerns events which are based on recreating the past through full-sized material (re)constructions in the form of open-air museums, reserves or archaeological parks as well as replicas of prehistoric strongholds or settlements (Pawleta, 2016, p. 164-166). An example can be a reconstruction of early medieval Slavic wooden stronghold in Owidz, about $50 \mathrm{~km}$ south of Gdańsk, opened in 2013. During its creation there was a lack of proper cooperation between the investor providing the tourist attraction and the group of archaeologists during the reconstruction of the area. In effect, this reconstruction is only partly based on archaeological research. Moreover, within the reconstruction a 'museum' was located where a range of weapons from different periods of history (including weapons of the Polish hussars and the French troops) is presented, which has no connection to the early medieval times (Jagodziński, 2015, p. 65). In order to increase its tourist attractiveness, the stronghold was further accompanied by a place with an amphitheater, piers for kayaks and a camping at the foot of an early medieval hillfort. That causes that it can hardly be called a reconstruction (Oniszczuk, 2014, p. 66) and serving other than commercial aims.

Another tendency, namely festivalisation of the past, describes events aimed at a mass audience, mainly in the form of archaeological festivals, fairs, markets or picnics (Pawleta, 2016, p. 169-170). They are open-air events which usually take place on historical sites (archaeological reserves, in the vicinity of strongholds, etc.), during which many aspects of material, social or spiritual life in the past are presented. An eminent example can be the Annual Archaeological Festival in Biskupin - one of Europe's largest archaeological open-air event (Chowaniec, 2017, p. 240-247). Once a year, over 70,000 of the 250,000 total yearly visitors to Biskupin, mostly schoolchildren, come to visit this largest and the most famous archaeological festival. Over a period of nine days, at the site of the archaeological reserve, the most varied aspects of human life from ancient times are presented. The festival is filled with live presentations of craftsmanship, combat as well as with music and dancing performances, 
methods of tanning leather, bone carving, weaving, spinning, prehistoric cooking, archery, crossbow shooting, coin stamping and much more. It also offers a wide range of catering and souvenir services.

The last tendency is theatralisation of the past (Pawleta, 2016, p. 166-169; 2017b) which should be understood as all modes of presenting in the front of lived audience and relating historical events, processes and persons with the use of theatrical practices - costumes, personalized drama, staging, etc. Seeing from such a perspective, archaeological fetes and historical re-enactments can be perceived as a spectacle or a show. An example can be the Traditional Celebration of Rękawka in Cracow, taking place on and around Krakus Mound - the city's oldest and most mysterious structure (Baraniecka-Olszewska, 2019). It gathers medieval re-enactors who travel from across Poland to establish a Slavic encampment around the Mound which aims for authenticity in the participants' attire, activities, shelter and food. Each year Celebration of Rękawka follows a different script and a new leading theme, although some of them are repeatable, as organized workshops on historical customs and craftsmanship, archery and other historical games for kids, plus historical costumes, goods and souvenirs for sale. More than just a fair, there is actually an entire programme for the day, highlights of which include for example the lighting of the Holy Fire, a medieval warrior run around the mound, a medieval battle, various short performances or plays and concerts.

Elements of commodification of the past can also be traced in approaching the past as a ludic phenomenon (Pawleta, 2012, 2018b). It can be argued that the past, as well as the forms of reference to it, can be an important source of ludic behaviour in present-day society. A distinction proposed by Ryszard Kantor, between "playing with the past" and "playing the past" can be referred to here. According to Kantor (2010, p. 136): "playing with the past" means "the use of props, characters and events from the past with the aim of amusement". Old costumes and clothes used today for fun, historical reconstructions and archaeological fettes belong to this category. They are purely entertaining performances, a form of passive entertainment, devoid of any educational potential. And "playing the past" has been defined by him as "a clearly distinct kind of human activity (participatory, active fun), more permanent and deeper" (Kantor (2010, p. 136). Participation in historical re-enactment societies and other group activities connected with the past are included in this category. Attention to historical accuracy is one of their important features.

And finally, quite different element constitutes casual adaptations of the symbolism of the past in the context of popular culture. It results from the fact that commercialisation of the past is not only done by the professional archaeological milieu, but also by amateurs and involves, for example, initiatives set up by people who do not have an academic archaeological background, e.g., re-enactment groups performing past events, exploited by amateurs for commercial purposes as tourist attractions, marketing products, etc. Such initiatives are not concerned with any educational or popularisation aims whatsoever, but are aimed solely at fulfilling consumer needs. They are focused on a mass audience and the fulfilment of various consumer needs 
relating to entertainment, the promise of experiencing something previously unknown and interesting through time or an aura of mystery. Exemplification of this trend can be seen in buildings stylised on ancient ones or the adaptation of historical buildings for contemporary needs, such as the medieval castles in the Kraków-Częstochowa Upland converted into hotels or private residences. An excellent example is also the ever popular 'Egyptomania'. In Tychy there was build the Piramida Hotel, based on the Pyramid of Cheops in Giza, the shape of which is meant to guarantee the hotel guests experience the flow of positive energy. The hotel has a pool, spa, conference facilities, bars and boutiques which in name, style and decoration use elements referring to ancient Egypt.

Commodification of the past has been strongly criticised by archaeologists or heritage specialists for bending scientific truth only in order to interest the viewer/ tourist, manipulation and simplification, a lack of scientific rigour or being dependant solely on the imagination of their creators. However, it does not necessarily have a negative meaning and should only be associated with a profit-seeking motives. Commercial initiatives can often play an important role in transmitting knowledge about the past in an attractive way and creating images of the past that enable people a wide access to the past. Nevertheless, the commodification of the past shows by its nature that the past for present-day people has acquired an exchange value.

\section{PAST AND IDENTITY: NOSTALGIA, NEOTRIBALISM AND NEW FORMS OF SPIRITUALITY}

Finally, the nature of the present-day attitude to the past is related to an individual's or group's search for/construction of identity. This is evident, for example, in the renaissance of Neopaganism, 'neotribalism' (Maffesoli, 1996) or in the promotion of a particular region together with the entire weight of its local traditions. Our times has created a specific attitude towards the past, namely nostalgia. The return to the past is partly coloured by contemporary nostalgia in reaction to the uncertainty of the moment in which people live (Lowenthal, 1985, p. 4). Such nostalgia for a lost past, on a personal level as much as a collective one, should be understood here as a particular attitude towards reality, characterised by a specific relationship to the past, one which makes the past a "depository of meaning and a gauge of values, an ideal fulfilled" (Zaleski, 2004, p. 12). In such context a return to the past can be observed, expressed, inter alia, in the need to identify with the past and ancestors. For example, being active in the re-enactment movement for some participants is seen as an escape from the present moment, which for certain reasons is painful or boring for them. Krzysztof Olechnicki and Tomasz Szlendak (2020, p. 9) call it 'a regressive utopia in action' while Wojciech Burszta (2013, p. 245) as 'adhering to the past'.

Also, Neopaganism that relates to important changes taking place in the world in the religious sphere, provides a good example here. In Poland, the term Neopagan is used to describe many different groups - Wiccans or Druids, and also groups of 
so-called ethnic Pagans invoking Celtic or Viking beliefs. The ethnic Pagan category includes Native Faith believers (Rodzimowiercy), who are a large group of the Pagans in Poland (Baraniecka-Olszewska, 2019, p. 159). Rodzimowierstwo is the Polish iteration of Slavic Native Faith, referring to

groups and individuals who practice a Slavic spirituality that acknowledges some form of polytheism or many forms of deity based in a continuation of Slavic traditions of the pre-Christian past, with emphasis on the use of historically and ethnographically reliable sources. (Simpson, Filip, 2013, p. 35)

The practices and beliefs of its followers are based on historical, archaeological and ethnographic materials concerning the Slavic religion, and also refer to elements taken from later Slavic folklore or from non-Slavic communities (Mesjasz, 2013; Simpson, 2013). Some members of the historical re-enactment movement, especially those recreating Early Medieval periods, profess their native faith, thus combining the practice of recreating the lives of the old Slavs with practising the same religion (Simpson, 2013, p. 118). The intertwining of their interest in historical re-enactment with conscious reference to Neopaganism in their life seems not accidental. What we observe here is the creation of the sense of historical and cultural identity and continuity with the ancestors. The need to continue the cultural heritage of the Slavs is indicated as the reason for the transition to paganism (Szczecińska-Musielak, 2009, p. 215).

Neo-pagans in Poland often refer to archaeological sites which are believed to have some connection with ancient rituals. An example can be the Mount Ślęża (Pawleta, 2017a). Ślęża is a place where pagan rituals were carried out in the past, and today Neopagans reconstruct and attempt to resurrect pagan traditions. For them, Ślęża is a sacred site, an important centre for prehistoric pagan cults. Pagan meetings held at the peak of the mountain aim to celebrate the pagan world, to honour pagan gods and forces of Nature. It is also an ideal place to celebrate important events in people's lives: marriages and other rites of passage. Nationalists have also chosen the site as a symbol of Slav strength. They hold meetings here and run training camps in the forests nearby. Another example can be referred here, namely stone circles from the Roman period in Pomerania (Pawleta, 2016, p. 408-417) that also serve as an emotional focus not only for collective, mainly local, but also for individual identities. Among them those inspired by the ideology of New Age or Neopaganism predominate. Many of them regard stone circles as sacred sites and gather there a number of times per year to celebrate the solstice and other pagan feasts, invoke tribal rituals or resurrect forgotten traditions.

What is also important from the issues discussed here is that historical re-enactment movement can be seen as an expression of a search for community and construction of individual and group identity. The contemporary consumer culture has introduced the possibility of immersing in the selected historical era to a degree which enables one to build one's 'alternative' identity (Olechnicki, Szlendak, 2020, p. 8). 
Apart from personal self-identification, re-enactment may also play a part in ethnic and/or religious identification of a person (or of a whole group of people) (Radtchenko, 2007, p. 134-135). First, the re-enactment milieus take the form of 'new tribes' groups in which the sense of community grows out of shared interests, ideals or views. This is a grass-roots movement that fits into the wider phenomenon of 'an obsessive search for the community', observed among Western societies at the turn of the $21^{\text {st }}$ century. In this context, participation in re-enactment groups can be viewed as a form of self-therapy, reaching to the roots, tradition, most distant history, which offers certainty, constructs identity, eliminates the sense of fear and offers them the sense of life, an explanation of the world surrounding the individual and its place in this world (Szczecińska-Musielak, 2009, p . 213). The very process of group formation and an active participation in a group can also satisfy the needs for safety and authority. Behind the idea to participate in the re-enactment movement is often the need for shared experience, being together with others; a response to "the need for intimate contacts lost in the globalising world" (Szpociński, 2012, p. 73).

However, participation in a re-enactment movement is not only about consociation but also about sharing a particular ethos. Based on certain components - values, personal patterns, norms or goals - reenactors construct their identity and lifestyle and legitimise them within certain groups or circles (Szczecińska-Musielak, 2009, p. 217). They form their own subculture within the society which is based on the positive valorisation of the past, usually of its own nation. Symptomatically, groups usually recreate the history of the community with which they identify themselves. In certain situations, this may have political overtones, when they choose to re-enact certain visions of the history of a given region (Szczecińska-Musielak, 2009, p. 221-222) what can be termed as 'an invented tradition' sensu Hobsbawn and Ranger (1983). In some instances, this somewhat imagined past evidenced in the engagement of some Polish Neopagans (mostly those with a connection to a Native Faith) with history and politics is often identified with nationalistic and or even racist conceptions of the national ideology. Yet, the attitudes Neopagans display toward the past, to national identity, or to political ideology are very diverse (Baraniecka-Olszewska, 2019, p. 164) and cannot be in every case conflated with extreme right-wing agendas.

\section{CONCLUSIONS}

In attempt to determine the attitude of contemporary Poles to the past, we need to place some phenomena in a wider perspective of its social and cultural conditioning that determine its specificity. The factors mentioned in my paper have led not only to changes in contemporary expectations and attitudes towards the past, how it is experienced or consumed, but also to a transformation in the hierarchy of aims and methods in education and the popularisation of knowledge about the past within institutions concerned with the past on a professional level. To a great extent, the observed dependencies exhibit common characteristics with the past created by archaeology, as 
the relationship with the past, understood as every form of reference to the past, is an element of culture as a whole and is dependent on similar mechanisms.

In my opinion, this altered situation demands a redefinition of the roles and position of archaeology, it is also a question of where this discipline is to be located in today's world, of which it is an element. A significant point, which I feel will define the direction archaeology in Poland will take, is the relationship between archaeologists and non-professionals, mainly where archaeological heritage interpretations and access to it are concerned. Although it is currently possible to observe the development - taking place outside of academia - of a range of references to the past, there is a lack - so far - of broader dialogue in this field. Theoretical reflection demands archaeologists leave their comfortable "ivory towers", not only to show the cognitive aims of their research, but also to take other discourse and perceptions of archaeological heritage into consideration. The issues raised here are decisive in not only how archaeology can be utilised in the public domain but they also determine archaeology's self-creation in today's world. Archaeology co-creates the reality and culture within which it participates, making it something more than just a discipline for the provision of knowledge on the subject of the past; archaeological interpretation is also an effective tool in its self-creation (Mamzer, 2004, p. 15).

In the face of this fast-changing reality, the related possibilities, challenges and dynamics of the discussed phenomena, the issues featured in the article most certainly demand much deeper investigation. I hope that by not exhausting the subject but rather simply outlining it, I have succeeded in showing beyond any doubt how necessary it is to examine the broad issue of the presence of the past in the contemporary world, the cultural and social aspects of its functioning from, above all, an archaeological perspective, progressing beyond the attempts to interpret and analyse which take place outside academic discourse.

\section{REFERENCES}

Baraniecka-Olszewska, K.

2018 Reko-rekonesans : praktyka autentyczności: antropologiczne studium odtwórstwa historycznego drugiej wojny światowej w Polsce. Kęty: Wydawnictwo Marek Derewiecki.

2019 The State Historical Policy and the Default Religious Heritage in Poland: On Introducing Pagan Heritage to the Public Sphere in Kraków. Etnografia Polska, 63(1-2), 155-168.

Bieszk, J.

2015 Stowiańscy królowie Lechii. Polska starożytna. Warszawa: Bellona.

2017a Chrześcijańscy królowie Lechii. Polska starożytna. Warszawa: Bellona.

2017b Królowie Lechii i Lechici w dziejach. Warszawa: Bellona.

2019 Starożytne królestwo Lehii. Kolejne dowody. Warszawa: Bellona.

Bogacki, M.

2007 Czy historia może być atrakcyjna? Czyli o przeszłości i jej „żywych” przejawach w początku XXI wieku. In K. Łopatecki, W. Walczak (eds), Zeszyty Dziedzictwa Kulturowego (p. 203-221). Białystok: Ośrodek Badań Europy Środkowo-Wschodniej. 
2008 Wybrane problemy odtwórstwa wczesnośredniowiecznego w Polsce. In M. Bogacki, M. Franz, Z. Pilarczyk (eds), Kultura ludów Morza Baltyckiego, t. 2. Nowożytność $i$ wspótczesność (p. 219-269). Toruń: Wydawnictwo Adam Marszałek.

Burszta, W. J.

2013 Przyleganie do przeszłości. In W. J. Burszta, Kotwice pewności. Wojny kulturowe z popnacjonalizmem w tle (p. 245-279). Warszawa: Iskry.

Chabiera, A., Dąbrowski A., Fortuna-Marek A. et al.

2017 Polacy wobec dziedzictwa. Raport z badań społecznych. Warszawa, Kraków: Narodowy Instytut Dziedzictwa, Uniwersytet Jagielloński. Online: https://www.nid.pl/pl/Wydawnictwa/inne\%20wydawnictwa/Polacy\%20wobec\%20dziedzictwa.\%20 Raport\%20z\%20 bada $\%$ C5\%84\%20spo\%C5\%82ecznych.PDF [dostęp: 20.06.2021]

Chowaniec, R.

2017 Archaeology for Everyone. Presenting Archaeological Heritage to the Public in Poland. Warszawa: Instytut Archeologii UW.

Fowler, P. J.

1992 The Past in Contemporary Society: Then, Now. London, New York: Routledge.

Grott, J.

2009 Consuming History. Historians and Heritage in Contemporary Popular Culture. London, New York: Routledge.

Hewison, R.

1987 The Heritage Industry. Britain in the Climate of Decline. London: Methuen.

Hobsbawn, E., Ranger, T. (eds)

1983 The Invention of Tradition. Cambridge: Cambridge University Press.

Jagodziński, J.

2015 Archaeological Research and the Development of Tourism in Poland - the Past, the Present, the Future. Muzeum Budownictwa Ludowego Park Etnograficzny w Olsztynku. Zeszyty Naukowe, 6(6), 61-70.

Jameson, J. H. Jr.

2008 Interpretation of Archaeology for the Public. In: D. M. Pearsall (ed.), Encyclopedia of Archaeology (p. 1529-1543). New York: Academic Press.

Kantor, R.

2010 Zabawa przeszłością - zabawa w przeszłość. Historia uludyczniona. Annales Universitatis Paedagogicae Cracoviensis. Studia Sociologica, 3, 134-149.

Kośnik, K.

2018 Internetowe narracje historyczne a słowiańska tożsamość Polaków. Prolegomena teoretyczna. Sensus Historiae, 30, 57-68.

2019 Virtual Historical 'Reality'. Identity Consequences of the Great Lechia Narratives. International Relations Review, 2(2), 199-209.

Kośnik, K., Filipiuk, J.

2016 Słowiańskie teorie spiskowe jako pozanaukowe narracje historyczne. Czas Kultury, 2, 82-97.

Kozioł, A., Trelka, M., Florjanowicz, P.

2013 Spoleczno-gospodarcze oddziatywanie dziedzictwa kulturowego. Raport z badań społecznych. Warszawa: Narodowy Instytut Dziedzictwa. Online: http://www.nid.pl/pl/Informa-

Krajewski, M. cje_ogolne/Aktualnosci/news.php?ID=2150 [dostęp: 20.06.2021]

2003 Kultury kultury popularnej. Poznań: Wydawnictwo Naukowe UAM.

Kukołowicz, T., Maciejczak, Z., Wiśniewski, R.

2018 Wymiary uczestnictwa Polaków we współczesnej kulturze historycznej. Kultura Wspótczesna, 100, 65-79. 
Kwiatkowski, P. T.

2008 Pamięć zbiorowa spoleczeństwa polskiego w okresie transformacji. Warszawa: Wydawnictwo Scholar.

2009 Czy lata III Rzeczypospolitej były „czasem pamięci”. In A. Szpociński (ed.), Pamięć zbiorowa jako czynnik integracji i źródto konfliktów (p. 125-166). Warszawa: Wydawnictwo Scholar.

2012 Kategoria przeszłości w potocznej pamięci zbiorowej. In E. Hałas (ed.), Kultura jako pamięć. Posttradycjonalne znaczenie przeszłości (p. 73-106). Kraków: Zakład Wydawniczy Nomos.

2014 Jaką historią interesują się Polacy? Pytanie o kształt pamięci zbiorowej i jej przemiany po 1989 roku. In: R. Kostro, K. Wóycicki, M. Wysocki (eds), Historia Polski od-nowa: nowe narracje historii i muzealne reprezentacje przeszłości (p. 119-158). Warszawa: Muzeum Historii Polski.

Lowenthal, D.

1985 The Past is a Foreign Country. Cambridge: Cambridge University Press.

1996 The Heritage Crusade and the Spoils of History. Cambridge: Cambridge University Press.

Lübbe, $\mathrm{H}$.

1991 Muzealizacja. O powiązaniu naszej teraźniejszości z przeszłością. In: M. Gołaszewska (ed.), Estetyka w świecie. Wybór tekstów, t. 3 (p. 7-29). Kraków: Uniwersytet Jagielloński.

Macdonald, S.

2013 Memorylands. Heritage and Identity in Europe Today. London: Routledge.

Maciejczak, Z.

2017 Doświadczanie przeszłości w kulturze współczesnej. Omówienie wyników najnowszych badań. Kultura Wspótczesna, 2(95), 274-279.

Maffesoli, M.

1996 The Times of the Tribes: The Decline of Individualism in Mass Society. London: Sage Publications.

Mamzer, $\mathrm{H}$.

2004 Archeologia i dyskurs. Rozważania metaarcheologiczne. Poznań: Instytut Archeologii i Etnologii PAN.

Mesjasz, K.

2013 'Tworzenie tradycji’ w rodzimowierczych związkach wyznaniowych. Studia Religiologi$c a, 46(2), 135-142$.

Murzyn, M., A.

2007 Cultural Heritage in Time of Change: Opportunities and Challenges. In: M. A. Murzyn, J. Purchla (eds.), Cultural Heritage in the $21^{\text {st }}$ Century. Opportunities and Challenges ( $\mathrm{p}$. 139-154). Cracow: International Cultural Centre.

Nieroba, E., Czerner, A., Szczepański, M., S.

2009 Między nostalgią a nadzieją. Dziedzictwo kulturowe jako dyskursywny obszar rzeczywistości społecznej. In E. Nieroba, A. Czerner, M. S. Szczepański (eds), Między nostalgia a nadzieja. Dziedzictwo kulturowe w ujęciu interdyscyplinarnym (p. 17-36). Opole: Wydawnictwo Uniwersytetu Opolskiego.

Nora, $\mathrm{P}$.

2009 Między pamięcią a historią: Les Lieux de Mémoire. Tytut Roboczy: Archiwum, 2, 4-12.

2010 Czas pamięci. Respublica Nowa, 10(200), 142-151.

Olechnicki, K., Szlendak, T.

2020 Historical Re-enactment in Poland: Between Faithfulness to History and the Imperative of Spectacularity. Polish Sociological Review, 1(209), 3-21.

Oniszczuk, A.

2014 The Convention in Action - Poland Almost 20 Years After the Ratification of the Valletta Convention. In V. M. van den Haas, P. A. C. Schut (eds), The Valletta Convention: Twenty 
Years After. Benefits, Problems, Challenges. EAC Occasional Paper No. 9 (p. 63-68). Brussel: Europae Archaeologia Consilium.

Pawleta, M.

2011 The Past Industry: Selected Aspects of the Commercialisation of the Past and Products of Archaeological Knowledge in Contemporary Poland. Sprawozdania Archeologiczne, 63, $5-54$.

2012 The Archaeological Fête in Ludic Space. In R. Chowaniec, W. Więckowski (eds), Archaeological Heritage: Methods of Education and Popularization (p. 133-140). Oxford: Archaeopress.

2016 Przeszłość we wspótczesności. Studium metodologiczne archeologicznie kreowanej przeszłości w przestrzeni społecznej. Poznań: Wydawnictwo Naukowe UAM.

2017a Past in the Present: Mount Ślęża According to Pierre Nora's "Sites of Memory" (Lieux de Mémoire) Concept. Folia Praehistorica Posnaniensia, 22, 155-177.

2017b Theatrum Archaeologicum: Staging the Past via Archaeological Fêtes and Historical Reenactment. Sprawozdania Archeologiczne, 69, 33-53.

2018a Historical Re-enactment as a New Form of Contemporary People's Relation to the Past. Sprawozdania Archeologiczne, 70, 147-167.

2018b The Ludification of the Archaeological Past - Opportunities and Threats. Analecta Archaeologica Ressoviensia, 13, 49-68.

2019 Archaeotourism Spaces in Present-day Poland: Thoughts on Reconstruction and Reenactments. In D. C. Comer, A.-M. Willems (eds), Feasible Management of Archaeological Heritage Sites Open to Tourism (p. 115-127). Cham: Springer.

Radtchenko, D.

2006 Simulating the Past: Reenactment and the Quest for Truth in Russia. Rethinking History, 10(1), 127-148.

Raport

2016 Raport z badania zrealizowanego na potrzeby wieloletniego programu rzadowego „Niepodległa". Warszawa: Narodowe Centrum Kultury.

Samuel, R.

1994 Theatres of Memory, Volume 1: Past and Present in Contemporary Culture. London: Verso.

Simpson, S.

2013 Polish Rodzimowierstwo: Strategies for (Re)constructing a Movement. In K. Aitamurto, S. Simpson (eds), Modern Pagan and Native Faith Movements in Central and Eastern Europe (p. 112-127). Durham, Bristol: Acumen Publishing Ltd.

Simpson, S., Filip, M.

2013 Selected Words for Modern Pagan and Native Faith Movements in Central and Eastern Europe. In K. Aitamurto, S. Simpson (eds), Modern Pagan and Native Faith Movements in Central and Eastern Europe (p. 27-43). Durham, Bristol: Acumen Publishing Ltd.

Szacka, B.

2009 Zmiany stosunku do przeszłości po przeobrażeniach ustrojowych 1989 roku w Polsce. Przegląd Filozoficzno-Literacki, 4(25), 415-427.

2014 Stosunek do przeszłości i jej przeżywanie w ponowoczesnym świecie popkultury. In E. Domańska, R. Stobiecki, T. Wiślicz (eds), Historia - dziś. Teoretyczne problemy wiedzy o przeszłości (p. 173-185). Kraków: Universitas.

Szczecińska-Musielak, E.

2009 Odgrywanie powrotów do przeszłości w rekonstrukcjach historycznych. In D. Rancew-Sikora, G. Woroniecka, C. Obracht-Prondzyński (eds), Kreacje i nostalgie. Antropologiczne spojrzenie na tradycje w nowoczesnych kontekstach (p. 209-218). Warszawa: Polskie Towarzystwo Socjologiczne. 
Szmygin, B.

2007 Heritage in Transformation. Polish Experience. In M. A. Murzyn, J. Purchla (eds), Cultural Heritage in the $21^{\text {st }}$ Century. Opportunities and Challenges (p. 129-138). Cracow: International Cultural Centre.

Szpociński, A.

2004a Tworzenie przestrzeni historycznej jako odpowiedź na nostalgię. Kultura Wspótczesna, $1(39), 58-67$.

2004b Współczesne społeczeństwo polskie wobec przeszłości. In A. Szpociński (ed.), Różnorodność procesów zmian. Transformacja niejedno ma imię (p. 151-175). Warszawa: Instytut Studiów Politycznych PAN.

2005a (ed.), Wobec przeszłości. Pamięć i przeszłość jako elementy kultury wspótczesnej. Warszawa: Instytut Adama Mickiewicza

2005b Pamięć przeszłości jako element kultury współczesnej. In A. Szpociński (ed.), Wobec przeszłości. Pamięć i przeszłość jako elementy kultury wspótczesnej (p. 5-17). Warszawa: Instytut Adama Mickiewicza.

2005c Autentyczność przeszłości jako problem kultury współczesnej. In A. Szpociński (ed.), Wobec przeszłości. Pamięć i przeszłość jako elementy kultury współczesnej (p. 292-302). Warszawa: Instytut Adama Mickiewicza.

2007 O współczesnej kulturze historycznej Polaków. In B. Korzeniewski (ed.), Przemiany pamięci spolecznej a teoria kultury (p. 25-43). Poznań: Instytut Zachodni.

2009 Wizualizacja pamięci społecznej. In A. Szpociński (ed.), Pamięć zbiorowa jako czynnik integracji i źródlo konfliktów (p. 227-237). Warszawa: Wydawnictwo Naukowe Scholar.

2010a Współczesna kultura historyczna. Kultura Wspótczesna, 1(63), 9-17.

$2010 \mathrm{~b}$ Poles Towards the Past. In: H. Best, A. Wenninger (eds), Landmark 1989. Central and Eastern European Societes Twenty Years After the System Change (p. 45-52). Berlin: LIT Verlag.

2012 Widowiska przeszłości. Pamięć jako wydarzenie. In E. Hałas (ed.), Kultura jako pamięć. Posttradycjonalne znaczenie przeszłości (p. 63-75). Kraków: Zakład Wydawniczy Nomos.

Szlendak, T., Nowiński, J., Olechnicki, K., Karwacki, A., Burszta, W. J.

2012 Dziedzictwo w akcji. Rekonstrukcja historyczna jako sposób uczestnictwa w kulturze. Warszawa: Narodowe Centrum Kultury.

Tarkowska, E.

2012 Pamięć w kulturze teraźniejszości. In E. Hałas (ed.), Kultura jako pamięć. Posttradycjonalne znaczenie przeszłości (p. 17-42). Kraków: Zakład Wydawniczy Nomos.

Urry, J.

2007 Spojrzenie turysty. Warszawa: Wydawnictwo Naukowe PWN.

Walsh, K.

1992 The Representation of the Past: Museums and Heritage in the Post-modern World. London - New York: Routledge.

Wójcik, A.

2019 Fantazmat wielkiej Lechii. Jak pseudonauka zawładnęła umysłami Polaków. Oświęcim: Wydawnictwo Napoleon V.

Wysocki, A.

2018 Stosunek społeczeństwa polskiego do przeszłości a tożsamość narodowa. Analiza badań sondażowych. Annales Universitatis Mariae-Curie-Skłodowska, 63(1), 111-124.

Zaleski, M.

2004 Formy pamięci. Gdańsk: Wydawnictwo Słowo/Obraz Terytoria.

Żuchowicz, R.

2018 Wielka Lechia. Źródła i przyczyny popularności teorii naukowej okiem historyka. Warszawa: Wydawnictwo Naukowe Sub Lupa. 


\title{
THE ATTITUDES OF THE CONTEMPORARY POLES TOWARDS THE ARCHAEOLOGICAL PAST
}

\author{
Streszczenie
}

Przedmiotem rozważań w artykule stanowią sposoby postrzegania przeszłości, stanowiącej przedmiot badań i namysłu archeologii, we współczesnych narracjach kulturowych. Jego głównym celem jest podjęcie próby zdefiniowania specyficznego, współczesnego stosunku do przeszłości. Wychodzę z założenia, że rozumienie i znaczenie przeszłości oraz w konsekwencji jej obrazów pozostają w ścisłej zależności z kulturą, która je kształtuje i tworzy, a także wpływa na stosunek ludzi do przeszłości. Znaczenie przeszłości na przestrzeni dziejów ulegało przeobrażeniom wraz ze zmianami kontekstu historycznego, w którym jej wizerunki były tworzone. Podobnie, zmiany w kulturze i postrzeganiu rzeczywistości w obecnych czasach doprowadziły do przewartościowania postaw ludzi wobec przeszłości.

Okres po 1989 r. w Polsce znamionuje przewartościowanie postaw i stosunku człowieka wobec przeszłości, co przejawia się m.in. w odmiennych niż dotychczas formach obecności i funkcjonowania przeszłości: jej reliktów, rekonstrukcji, narracji, jak również sposobach odnoszenia się do przeszłości. Argumentuję, że zostały one uwarunkowane powiązanymi ze sobą czynnikami ekonomicznymi, kulturowymi i społecznymi. Zmiany te - oprócz przemian w łonie samej dyscypliny, będące konsekwencją wyżej wymienionych transformacji, wywarły wpływ na wizerunki przeszłości, kreowane przez archeologię, dziedzictwo archeologiczne - sposoby jego ochrony, zarządzania i udostępniania, a także zakres funkcjonowania archeologii. W artykule uzasadniam tezę, że charakter dynamicznych zmian kulturowych, społecznych, politycznych, gospodarczych i cywilizacyjnych, które kształtują współczesność, formułuje całkiem nowy kontekst dla funkcjonowania przeszłości.

Obrana formuła argumentacji w artykule nie jest kompletnym rejestrem zjawisk. Wręcz przeciwnie, jest ma on charakter problemowy i opiera się na analizie, opartej na wybranych przykładach projektów archeologicznych, pewnych szerszych problemów, zjawisk i trendów, charakterystycznych dla okresu po 1989 r.

W artykule w kolejności zostały omówione współczesne zmiany w stosunku człowieka obecnych czasów do przeszłości. Następnie na wybranych przykładach archeologicznych, a także zjawiskach spoza dyskursu akademickiego (m.in. fenomen Wielkiej Lechii, neopogaństwo) analizuję zagadnienie demokratyzacji i prywatyzacji przeszłości, próby nawiązania bezpośredniego, zmysłowego kontaktu z przeszłością, komercjalizację i utowarownienie przeszłości, a także zagadnienia odnoszące się do kreowania tożsamości opartej na przeszłości, w tym przeszłości archeologicznej (m.in. nostalgia, nowoplemienność i nowe formuły duchowości). 
